\title{
Education and religion: Individual, congregational, and cross-level interaction effects on biblical literalism 证, 败败
}

\author{
Samuel Stroope* \\ Department of Sociology, Baylor University, United States
}

\section{A R T I C L E I N F O}

\section{Article history:}

Received 11 December 2010

Revised 16 May 2011

Accepted 19 May 2011

Available online 26 May 2011

\section{Keywords:}

Stratification

Education

Organizations

Social networks

Culture

Religion

Beliefs

Congregations

\begin{abstract}
A B S T R A C T
Using ideas from cultural and organizational theory, I examine the interplay of individual and congregation-level educational attainment on biblical literalism. Data on 387 congregations and 100,009 worshippers (US Congregational Life Survey, 2001) are used to test hypotheses. Results indicate that the effects of congregational education and individual educational attainment are among the largest effects in models. This study is the first to show that regardless of an individual's own education, affirmations of biblical literalism are less likely when persons with higher education dominate a congregation. This finding brings into relief the important role of social context in persons' belief in biblical literalism. Additionally, congregational education amplifies the influence of individual education on biblical literalism such that the gap in belief between college/non-college education individuals widens in high education congregations. This finding suggests that high education persons more deeply absorb the influence of a more educated congregational context.
\end{abstract}

(c) 2011 Elsevier Inc. All rights reserved.

\section{Introduction}

A growing body of literature documents the importance of belief in the Bible for religious and nonreligious outcomes. Biblical literalism, the focal concern in this literature, represents not only a dividing line in religious communities but also remains important more broadly because of its association with various outcomes such as civil liberties attitudes (Froese et al., 2008). But there remain unanswered questions about what shapes literalist views of the Bible. Social class-based experiences often mold internal dispositions, including belief commitments, in enduring ways (Bourdieu, 1984); similarly, stratifying experiences, such as educational attainment, shape beliefs about the Bible. Educational attainment is particularly relevant to biblical literalism because Americans spend an increasing number of years enrolled in schools and colleges, and part of the expansion of formal education in the United States has meant that many more conservative Christians, including biblical literalists, are exposed to unprecedented levels of formal education. Biblical literalists' increased experience with educational institutions is partly due to the improved representation of women and ethnic and racial minorities in higher education, groups more likely to adhere to a literal view of the Bible. What consequences might the expansion of education and the dominance of congregations by college graduates have for biblical literalism?

Secularization proponents generally hold that the modernization of societies, including scientific and educational advancement, reduces religiosity. Past sociological literature sees higher education in particular as a secularizing force (Hunter, 1987; Wuthnow, 1988). Though this earlier work contends that diminished religiosity accompanies increased

\footnotetext{
Thanks to Paul Froese, Joseph Baker, Troy Blanchard, Charles Tolbert, Jerry Park, Chris Bader, Phillip Connor, Brandon Vaidyanathan, the editor and anonymous Social Science Research reviewers for comments on this article. Thanks to Andrew Whitehead and Scott Draper for productive conversation.

Winner, 2011 Robert J. McNamara Student Paper Award from the Association for the Sociology of Religion.

* Address: Department of Sociology, One Bear Place \#97326, Baylor University, Waco, TX 76798-7326, United States.

E-mail address: sam_stroope@baylor.edu
} 
education, recent research complicates this picture, showing that the college educated may be more religious than young adults who do not attend college (Uecker et al., 2007). ${ }^{1}$ This education-religion puzzle directs our attention away from examining whether or not schooling uniformly secularizes, to consider how educational attainment may differentially affect particular religious practices or beliefs. Higher education is known to cultivate a range of beliefs in areas such as political tolerance, civil rights, and altruism (Hyman and Wright, 1979; Pascarella and Terenzini, 2005). But a recent review of the college-religion literature finds that "research has not provided a compelling answer to the question of how the college experience affects the content of [religious] beliefs" (Mayrl and Oeur, 2009, p. 264).

In this article, I argue that it is not enough to examine this question in view of individuals' own educational backgrounds; rather, the role of social context must be brought into relief. Specifically, I reason that the educational make-up of congregations is a key factor in understanding the influence of education on the maintenance of religious belief, and specifically beliefs about the Bible. This focus is in line with a long-standing sociological tradition maintaining that individuals' personal backgrounds as well as individuals' social context shape beliefs, including religious beliefs. Simmel (1898, p. 108) spoke explicitly to this notion: "the faith that has come to be regarded as the essence and substance of religion is first of all a relationship between human beings" (emphasis in original). Consistent with this tradition, scholars have distinguished between individuals' within-denominational social ties and within-congregation social ties, the latter highlighted as especially important for shaping religious behavior and belief (Cornwall, 1987, 1989). There are a variety of reasons why higher education should particularly affect beliefs about the Bible. Some of these reasons revolve around personal experiences in college, but others stem from being surrounded by fellow congregants who are college graduates. Such a high education social context may amplify the influence congregants' educational experiences have on each others' view of the Bible. It follows that the educational composition of these "interpretive communities" should have strong bearing on the maintenance of biblical literalism among members (Bartkowski, 1996, p. 269). The influence of congregants' higher education background on an individual congregant's biblical belief should be considered an important piece to the education-religion puzzle.

The present study contributes to the education-religion literature by tying together several lines of research and theory indicating that congregational and individual educational attainment should interact in a multilevel framework to diminish affirmations of biblical literalism. Following previous work and theory (Hoffmann and Bartkowski, 2008), I understand the literal view of the Bible as a cultural schema shaped by both individual and social structural resources. I build on previous work on the social sources of biblical literalism by examining the effects of educational attainment at both individual and group levels. Sociological theories of religion expect congregational contexts to condition individual-level effects, but until recently, data and methodological limitations have hindered researchers' opportunities to model hypothesized multilevel relationships. As a result, no scholarly work has examined how the educational composition of congregations shapes view of the Bible. Additionally, few studies of educational effects on religion compare college attendees with non-attendees. To fill these gaps and build on the education-religion research literature, the present study uses a recent national survey, analyzing 100,009 individuals nested in 387 congregations using multilevel modeling, to test hypotheses concerning educational effects at the congregation and individual level and their cross-level interaction. In interpreting results, I import the idea of "absorptive capacity" from organizational literature to help illuminate the tendency of more educated individuals to be more strongly swayed by more educated congregational environments.

\section{Background}

\subsection{Biblical literalism}

A central aspect of Christian groups' divisions and conflicts has centered on view of the Bible (Ammerman, 1987). Scholars of religious fundamentalism count belief in scriptural inerrancy and literalism as key identifiers of fundamentalism (Almond et al., 1995; Hood et al., 2005). Survey researchers frequently use literal interpretation of the Bible as a measure of Christian fundamentalist orientation (Jelen et al., 1990), with variation in biblical literalism found within both traditionally conservative and liberal denominations (Village, 2005; Woodberry and Smith, 1998). Consistent with previous literature (e.g., Hoffmann and Bartkowski, 2008), biblical literalism is understood in this study as taking everything in the Bible as the literal word of God (as opposed to non-literalists who do not take some biblical passages literally, word-for-word). Contemporary biblical literalism is largely the descendant of a theological orientation popularized during the early fundamentalist movement in the United States in the late nineteenth century (Marsden, 1980). Around this time, Evangelicals had become increasingly marginalized in America's cultural centers (e.g., the academy) and the promotion of a literalist hermeneutical orientation became one attempt to maintain religious fidelity in an intellectual climate skeptical of the Bible's authority and timeless validity (Marsden, 1994). Despite this relatively recent popularity of biblical literalism within the American context, an ongoing research literature has devoted considerable attention to biblical literalism with good reason. Studies repeatedly demonstrate that biblical literalism is related to a wide variety of religious and non-religious social outcomes and attitudes (Froese and Bader, 2010). Among these is biblical literalism's association with political intolerance (Froese et al., 2008), criminal punishment attitudes (Bader et al., 2010), reduced verbal ability (Sherkat, 2010), limited educational enrollment (Darnell and Sherkat, 1997), lower exposure to pornography (Sherkat and Ellison, 1997), lower marital infidelity

\footnotetext{
${ }^{1}$ Others have also found college to either have a positive effect (Dillon, 1996; Lee, 2002) or no effect (Arnett and Jensen, 2002) on religiosity.
} 
(Burdette et al., 2007), increased corporal punishment and reduced parental shouting (Bartkowski and Wilcox, 2000), and weaker environmentalism (Wolkomir et al., 1997; but see Sherkat and Ellison, 2007). The effects of biblical literalism merit ongoing attention, as do the phenomenon's social antecedents.

A variety of factors are known to affect literal view of the Bible, among them: religious tradition, images of God as judicial or engaged, southern residence, nonwhite race, and educational attainment (Froese and Bader, 2007; Bader and Froese, 2005). In examining the social sources of American religious restructuring following World War II, Wuthnow (1988, p. 168) underscores the importance of educational expansion and argues that "of all the social background questions ... education was the factor that most clearly discriminated between religious liberals and religious conservatives." Furthermore, "views of the Bible ... were one of the issues on which the better and less educated divided most sharply" (Wuthnow, 1988, p. 168). This distance between educational attainment on the one hand and religious conservatism on the other, is also in part linked to the twentieth century ascendance of science as a supreme authority (Smith, 2003a).

Recent applications of a schema-resource theoretical model to biblical literalism offer further insight into how views of the Bible are shaped by factors such as educational expansion. For example, scholars have examined biblical literalism as both a cultural schema and a gendered power resource for women in patriarchal religious organizations (Hoffmann and Bartkowski, 2008). Building on earlier uses of a schema-resource model (Sherkat, 1998) and gender theory, Hoffmann and Bartkowski examine literalism as a schematic mental orientation that organizes attitudes and action, but is also patterned by physical and social resources, as well as other distinct mental schemas (Sewell, 1992, 2005). When conceived as a cultural schema, not only might biblical literalism influence resources, but resources, both religious and non-religious, should come to shape an individual's biblicist schema. Resources may also structure schemas by allowing contradictory schemas to influence a given domain. Sewell (1992, p. 8) directly addressed this scenario: "Schemas can be used not only in the situation in which they were first learned or most conventionally applied. They can be generalized-that is, transposed or extended-to new situations when the opportunity arises." In this way, overlapping schemas need not be congruent; they may be in direct conflict in certain matters. For example, just as scientific schemas may be perceived as in conflict with specific religious schemas in terms of truth claims, so too exposure to educational systems that promote a scientific schema, for example, may compete with religious schemas that organize views of knowledge, truth, and morality differently. Biblical literalism is a fitting religious schema in this scenario. If a literal view of the Bible is a "default" orientation for contemporary church-goers (Village, 2007, p. 70), educational attainment likely represents the degree to which people have been exposed to competing truth claims or cultural or moral positions that run counter to strict biblicist perspectives.

\subsection{Education and biblical literalism}

Religious conservatives contend that mainstream education weakens orthodox religious commitment (Darnell and Sherkat, 1997), and there may be merit to this claim in the case of adherence to a literal view of the Bible. Past studies have argued that educational attainment reduces adherence to traditional religion (Wuthnow, 1988, pp. 154-172; Himmelfarb, 1979), including a literal orientation to the Bible (Roof and McKinney, 1987). Educational attainment shapes various beliefs and attitudes in lasting ways (Funk and Willits, 1987; Pallas, 2000), and many institutions of higher education are known to communicate messages to students that run counter to the orientations of conservative Christians (Sherkat and Darnell, 1999; Sikkink, 1999; Pascarella and Terenzini, 2005). Conceiving of educational attainment as both resource and schema helps to broadly conceptualize education's influence on biblical literalism.

\subsubsection{Resources}

There are several ways that educational attainment may expose individuals to resources that make a literal view of the Bible less likely. First, educational attainment alters literalist schemas of biblical interpretation because the explicit didactic goal of much of education, particularly higher education, is to impart a critical approach to historical material and literary texts. Such critical orientations to the biblical text encourage reading passages in broader context, identifying literary genres, using background historical material, thinking about redactions, as well as other considerations. All of these ways of understanding literature and historical documents may eschew a biblical literalism schema that approaches the Bible word-for-word without strong consideration of literary devices, historical sources, or scientific information. Second, sustained exposure to educators may erode student commitment to Biblicism. With greater educational experience often comes influence from educators such as professors who are less likely than the general population to adhere to traditional religious practices or beliefs, such as literalist views of the Bible (Ecklund and Park, 2009; Ecklund and Scheitle, 2007). For example, in recent research, $48 \%$ of college professors and $72 \%$ of professors at elite research universities report viewing the Bible as a "book of fables" (Gross and Simmons, 2009). Educators and professors are influential sources of guidance and modeling in many students' lives because they possess considerable symbolic capital and occupy cultural positions of legitimacy and authority. As such, educators come to influence students' opinions, aspirations, and tastes on a variety of topics, including cultural and religious beliefs (Smith and Snell, 2009).

Third, educators and curricula generally expose students to information and theories that challenge or complicate traditional religious beliefs (Reimer, 2010). For example, being taught materials highlighting the scientific contribution of Darwinism for understanding human origins may become irreconcilable with literalist views of scripture (Marsden, 1980). Literal readings of explanations for human and natural events taken from the Bible are often also in conflict with explanations provided in secular educational environments (Hood et al., 2005). Finally, in most cases, educational attainment 
means immersion in pluralistic contexts where biblical literalists are more likely to encounter diverse others who may challenge a biblicist worldview. Movement into the college-age life stage is accompanied by relocation in social networks that are more likely to be less religious than those of childhood and adolescence (Smith and Snell, 2009, p. 75). In a similar vein, because biblicist students are usually a minority in most colleges and universities, such students are more likely to encounter and form relational ties with peers who hold non-literalist views of the Bible or who believe in different scriptures such as the Bhagavad Gita, or who do respect any religious scriptures (Sherkat, 2007). Such dislocation from old plausibility structures and submersion in dominant networks and accompanying cultural beliefs is well documented in the migration and religion literature (Connor, 2009; Stump, 1984; Wuthnow and Christiano, 1979). Even most religious colleges are unlikely to promote a literalist interpretation of the Bible, and religiously conservative colleges make up a very small proportion of America's institutions of higher education.

\subsubsection{Schemas}

In addition to providing anti-literalist resources, educational experience may bolster schemas that compete with biblical literalism. Sewell (2005, p. 209) addresses this possibility directly: "given that structures overlap, cultural meanings and identities derived from one structure or institutional sphere can be transposed to others." There are several ways this may happen in the case of educational schemas and biblicist schemas. First, educational institutions promote a scientific worldview frequently in tension with literal readings of scripture (Cherry et al., 2001). The scientific worldview explains that the earth is billions of years old, in contradiction to many literalists' young earth readings of biblical texts. Second, educational institutions are not only socializing contexts for intellectual development, but also for moral formation. Studies have found that increased exposure to educational contexts is positively associated with more liberal cultural tastes and moral orientations (Ohlander et al., 2005; Wilcox, 1992; Walzer, 1994). Longer exposure to educational systems promotes liberal schemas of morality and weakens conservative moral commitments. Likewise, this schematic arrangement should also weaken biblical literalism. In support of this idea, recent work on the relationship between science and religion suggests that conflicts may not be due to competing truth claims, but rather competing moral claims (Evans and Evans, 2010).

Third, scholars maintain that educational attainment has increased cultural salience in wealthy post-industrial societies and such cultural resources take on greater importance as stratifying social commodities (Bell, 1973; Bruce-Briggs, 1979; Wuthnow, 1988, p. 163). More than simply imparting information and cognitive skills, educational experiences come to shape lasting cultural boundaries between people of differing educational backgrounds (Bourdieu, 1984). These boundaries promote homogeneity in cultural tastes and attitudes within educational subcultures or status groups (Kalmijn and Kraaykamp, 2007). Biblical literalism would likely be sanctioned as a kind of cognitive deviance among those with higher educational attainment and its associated cultural tastes. Finally, education promotes not only liberal moral schemas, but also schemas of religious pluralism that negate claims to religious exclusivity based on word-for-word readings of biblical passages (Smith and Snell, 2009, p. 101). ${ }^{2}$ Affirming the salvific sufficiency of non-biblical religions or even allowing the possibility of truth in other religions generally runs counter to literalist biblical schemas. Taken together, the above discussion suggests, as others have asserted (Marsden, 1994), that schemas normative in most American educational institutions are generally averse to many forms of conservative religious belief such as biblical literalism. Despite observations of religiosity among students on contemporary university campuses (Cherry et al., 2001), such signs of religious vitality in the academy do not specifically preclude the erosion of certain beliefs, such as belief in a literal Bible.

\subsection{Congregational context and biblical literalism}

What role do fellow worshippers' educational backgrounds play in people's religious beliefs? In addition to the effects of an individual's educational experiences, the educational attainment of others in one's religious congregation may also erode literal views of the Bible. Social structural contexts are known to impact individual cultural schemas (Sherkat, 2010). Plausibility structures, bounded social worlds of cognitively similar others, help support traditional religious commitment (Berger, 1967; Regnerus et al., 2004). While various kinds of religious social networks may be important for shaping religious beliefs, Wuthnow (1996, p. 324) emphasizes that it is often the social context of "congregations that provide affirming plausibility structures" shaping religious schemas. Other sociologists of religion have similarly noted that interaction in religious congregations is especially important for a variety of religious outcomes, including beliefs (Smith, 2003b; Stark and Bainbridge, 1980). Furthermore, scholars have argued that literal biblical interpretations are not mainly formed through personal Bible study, but through an interpretive community in which the person is embedded (Ellison and Bartkowski, 1997; Ellison and Sherkat, 1993; Ammerman, 1987).

Some congregational contexts may also make belief in biblical literalism less likely. It is not just interaction in a religious group that is important for beliefs. Nor are different denominational teachings necessarily all that matter for individuals' beliefs. The make-up of a congregation and particularly the characteristics of numerically dominant members determine in which direction a group pulls an individual (Gould, 2003). Consistent with Sewell (2005, p. 209), religious communities can be understood as "sites of a multitude of overlapping and interlocking cultural structures." The social context of congregations may bolster biblical literalism, providing subtle sanctions when congregants stray from literal ways of interpreting

\footnotetext{
${ }^{2}$ For earlier generations, higher education may have promoted strongly secular schemas, also at odds with literalism (Pascarella and Terenzini, 2005).
} 
scripture (Sherkat and Cunningham, 1998). On the other hand, the social context may work against biblical literalism, facilitating schemas that compete with a biblicist perspective. One important aspect of the composition of a congregational context that should have implications for individual's view of the Bible is the educational background of fellow congregants. Wuthnow (1988, p. 160) suggests that not only greater educational expansion in the general population, but higher proportions of college educated parishioners in churches are important in understanding shifts toward religious liberalism. This is an ongoing consideration because conservative religious groups are retaining more of their highly educated members, partially because educationally advanced members are less likely to switch to other denominations than in the past (Hout et al., 2001; Lindsay, 2007). Higher education among congregants should bring with it many factors similar to the effects of an individual's educational attainment on their biblical literalism as previously discussed. Because of these pluralistic, cognitive, and evaluative effects of higher education, greater numbers of the college educated in congregations should influence members' biblical literalism.

Recent organizational research indicates that it is not only the characteristics of a context that influences individuals positioned within a context, but it is also the individual's "absorptive capacity," that is, some individuals "may be able to access knowledge through [their] network links but [others] may not have sufficient capacity to absorb such knowledge" (Tsai, 2001, p. 1003). Introducing this insight into the present subject matter suggests that an individual with greater educational attainment should be better able to absorb the influence of a more educated congregational context, and this absorption should heighten the effect of congregational context on biblical literalism. Such an organizational process also comports with a schema-resource model. Congregational education consists of resources that shape a variety of schemas and also shape how those schemas influence each other. Research on congregations is consistent with this view, showing for instance that group theology increases the effects of individual theology on church-based friendship formation (Scheitle and Adamczyk, 2009). In this way, the resources in a social context tip the scales in the battle for dominance between multiple cultural schemas competing for ascendancy in a person's mind. Applied to this study's concerns, the educational backgrounds of persons in a social context should impact an individual's cultural schemas. Values, beliefs, cognitive styles, and skills that stand in opposition to biblical literalism become activated or stronger when surrounded by others with schemas similarly antithetical to literalism. For example, a person with greater educational experience might be more likely to think about the genre of a biblical passage and how it should be interpreted metaphorically when surrounded by congregants familiar with modern literary criticism, cultural contexts of the Ancient Near East, and other ideas acquired in institutions of higher education.

\subsection{Hypotheses}

The above discussion motivates several specific empirical expectations, which will focus the remainder of the study:

H1. Individual educational attainment will decrease the likelihood of affirming biblical literalism.

H2. Individuals in congregations with a higher proportion of college graduate attendees will be less likely to affirm a literal view of the Bible, regardless of individuals' own educational attainment.

H3. Greater congregational dominance of college graduates will increase the effect of individual educational attainment on biblical literalism.

\section{Data and methods}

To test these hypotheses, I analyze data from the US Congregational Life Survey (USCLS), conducted in 2001 among 122,404 individuals from 424 congregations. Hypernetwork sampling was used in drawing the random sample of the USCLS. The USCLS employs a national sample of 1214 congregations obtained by the University of Chicago-based National Opinion Research Center in 2000. Of these, 34\% completed a congregational survey and attendee surveys. ${ }^{3}$ Researchers have found the USCLS data to be demographically comparable to those of the 1998 National Congregations Study (Hill and Olson, 2009). Organizational characteristics of the USCLS congregations were captured through the congregational survey, completed by a knowledgeable leader in each congregation. All congregants in attendance at a weekend worship service in April of 2001 completed the attendee survey. The attendee survey gathered data on individual sociodemographics, beliefs, and behaviors. ${ }^{4} \mathrm{About} 9.9 \%$ of respondents did not provide household income information. The average percent of missing data for the remaining variables in this study is $1.9 \%$ (several items had no missing data: age, race, and number of children present in the home). For those congregations for which there is some missing information on individual-level variables, ${ }^{5}$ I use the multiple imputation procedure from SAS 9 to generate five imputed data sets which are then used in all analyses. Multiple imputation has the advantage of

\footnotetext{
${ }^{3}$ Researchers have provided evidence indicating that the precision of parameter estimates using sample data are minimally related to response rates (American Association for Public Opinion Research, 2008; Singer, 2006).

4 See Woolever and Bruce (2002) for more information on methods and sampling procedures used in the USCLS.

${ }^{5}$ I excluded cases that initially had missing values on the dependent variable (Von Hippel, 2007).
} 
maximizing the use of missing information. The technique also represents the ambiguity inherent in imputed data by modifying standard errors (Allison, 2001). The final regression coefficients are summarized parameter estimates of five multilevel models from using the imputed datasets (Rubin, 1987). The end analytic sample consists of 100,009 individuals nested in 387 congregations. ${ }^{6}$ This final sample excludes respondents younger than 18 years of age.

\subsection{Dependent variable}

To measure biblical literalism, the USCLS asked: "Which statement comes closest to your view of the Bible?" The seven possible responses to this question were (1) The Bible is the word of God, to be taken literally word for word; (2) The Bible is the word of God, to be interpreted in the light of its historical and cultural context; (3) The Bible is the word of God, to be interpreted in the light of its historical context and the Church's teachings; (4) The Bible is not the word of God, but contains God's word to us; (5) The Bible is not the word of God but is a valuable book; (6) The Bible is an ancient book with little value today; and (7) Don't know. Biblical literalism is coded as a binary variable ( $1=$ "literally word for word"). Averaged over all congregations, biblical literalists make up $27 \%$ of respondents. Percent literalist in congregations ranges from $0 \%$ to $100 \%$ $($ mean $=.35)$.

\subsection{Independent variables}

Individuals' educational attainment is measured with a question that asked "What is the highest educational level you have completed?" Possible responses were (1) no formal schooling; (2) primary through 8th grade; (3) some high school; (4) completed high school; (5) trade certificate; (6) associate degree; (7) bachelor's degree; (8) Master's, Doctorate, or other graduate degree (mean $=5.5$ ). Half of respondents $(52 \%)$ completed high school but no more, $25 \%$ earned a bachelor's degree but no more, and $15 \%$ hold a graduate degree.

In addition to this key independent variable, I also control for several other potentially confounding factors at the individual level. Because prior work finds nonwhites are more likely to affirm biblical literalism (Froese and Bader, 2007); race/ ethnicity is controlled with dichotomous indicators: black, Asian, Hispanic, and white. I also account for gender $(\mathrm{female}=1$ ) because women may make up for being denied leadership roles by affirming a literal view of the Bible, i.e. a view that validates submission (Hoffmann and Bartkowski, 2008). Age tends to be positively related to biblical literalism (Schwadel, 2011); I measure age in years (18-101). Marriage often promotes traditional religious commitments (Thornton et al., 1992), and since marrying outside one's denomination is associated with lower religious commitment (Iannaccone, 1994), attending church together with a spouse should help maintain religious beliefs. With these marriage partner effects in mind, I distinguish between respondents who are married (1) and those who are not (0); additionally, whether or not a respondent's spouse attends the same congregation $(0,1)$. Research also suggests that parents may shore up their own religious commitments in an effort to give children guiding beliefs for life (Ingersoll-Dayton et al., 2002). Because of this tendency, the analyses include a measure of whether or not a child lives in the home (yes $=1$ ). I control for income (less than $\$ 10,000-\$ 100,000$ or more); Norris and Inglehart (2004) argue that material security diminishes attachment to religious beliefs (but see Stroope, 2011). Following the idea that the maintenance of religious belief depends on social integration in the fellowship of believers (Berger, 1967; Lofland and Stark, 1965), I also include measures for frequency of worship service attendance (1-7), longevity of attendance at the congregation (1-8), and congregational friends (1-4). The congregational friends item comes from a question that asked about the proportion of a respondent's friends that are in the same congregation: "do you have any close friends in this congregation?" Possible responses ranged from "No, I have little contact with others from this congregation outside of activities here" to "Yes, most of my closest friends are part of this congregation."

Congregational education is constructed from the percent of respondents in the congregation whose highest educational attainment is a bachelor's degree. This cutting point was chosen because of the importance of the college experience in the research literature (Mayrl and Oeur, 2009). Person's with a greater than bachelor's degree clearly have greater exposure to higher education, but the bachelor's degree or greater group all have in common significant amounts of exposure to higher education. ${ }^{7}$ This variable ranges from $0 \%$ to $91 \%$ (mean $=35 \%$ ). Congregation-level controls are as follows. The USCLS recorded the denominational affiliation of each congregation. Affiliations are coded into a series of standard religious tradition binary variables: Evangelical Protestant, Mainline Protestant, Catholic, and Other. I control for the number of attendees at a

\footnotetext{
${ }^{6}$ Prior multilevel studies using USCLS limited analyses only to persons who completed questions on all analytic variables (Scheitle and Adamczyk, 2009; Scheitle and Finke, 2008). I extend this previous work by including individuals with missing values on some variables. I use multiple imputation which typically assumes data are missing at random (MAR) (Allison, 2001, pp. 77-78). MAR assumes that the probability that variable $\mathrm{x} 1$ is missing for a respondent may be associated with the respondent's values of variables $\times 2$ and $\times 3$, but not to its value of $\times 1$. MAR is less stringent than the assumption that data are missing completely at random (MCAR), a special instance of MAR. MCAR requires that missingness is not related to any variables in the sample; all cases must have the same chance of being missing. Looking at the USCLS data, I find that biblical literalists are more likely to have missing data than nonliteralists. Additionally, persons with less education are more likely to have missing data. MCAR therefore cannot be assumed. But exploratory analyses were not informative regarding the less demanding standard of MAR. Persons with less education may be less likely to complete surveys regardless of their potential responses, and biblical literalists are more likely to be persons with less education.

${ }^{7}$ I also conducted analyses with a mean congregational education measure, aggregating a continues rather than dichotomous individual-level education measure. Results of multilevel models did not change in any substantial ways.
} 
Table 1

Descriptive statistics.

\begin{tabular}{|c|c|c|c|c|}
\hline & Mean & SD & Min & Max \\
\hline \multicolumn{5}{|l|}{ Dependent variable } \\
\hline Biblical literalism & 0.27 & 0.45 & 0 & 1 \\
\hline \multicolumn{5}{|l|}{ Congregation-level variables } \\
\hline Evangelical protestant & 0.29 & 0.45 & 0 & 1 \\
\hline Mainline protestant & 0.40 & 0.49 & 0 & 1 \\
\hline Catholic & 0.24 & 0.43 & 0 & 1 \\
\hline Other & 0.07 & 0.26 & 0 & 1 \\
\hline Size (LN) & 5.90 & 1.26 & 2.30 & 8.88 \\
\hline South & 0.34 & 0.47 & 0 & 1 \\
\hline Proportion college graduate & 0.35 & 0.20 & 0 & 0.91 \\
\hline \multicolumn{5}{|l|}{ Individual-level variables } \\
\hline Age & 51.95 & 16.89 & 18 & 101 \\
\hline Female & 0.61 & 0.49 & 0 & 1 \\
\hline Married & 0.56 & 0.50 & 0 & 1 \\
\hline Child at home & 0.59 & 0.49 & 0 & 1 \\
\hline Income & 3.55 & 1.48 & 1 & 6 \\
\hline White & 0.74 & 0.44 & 0 & 1 \\
\hline Asian & 0.04 & 0.20 & 0 & 1 \\
\hline Black & 0.04 & 0.20 & 0 & 1 \\
\hline Hispanic & 0.12 & 0.33 & 0 & 1 \\
\hline Other race & 0.03 & 0.16 & 0 & 1 \\
\hline Service attendance & 5.68 & 1.20 & 1 & 7 \\
\hline Length of time at church & 5.87 & 1.93 & 1 & 8 \\
\hline Congregational spouse & 0.51 & 0.50 & 0 & 1 \\
\hline Congregational friends & 2.63 & 0.91 & 1 & 4 \\
\hline Educational attainment & 5.49 & 1.77 & 1 & 8 \\
\hline
\end{tabular}

Note: Descriptive statistics of independent variables are after imputation.

congregation because large size tends to vary inversely with the religious commitment of congregants (Dougherty and Andrew, 2011; Whitehead, 2010). The natural log of congregation size is taken due to positive skew. Finally, I also control for whether or not the congregation is located in the South $(0,1)$. Means, standard deviations, and response ranges are presented in Table $1 .{ }^{8}$

\subsection{Analytic method}

I analyze the interplay between organizational characteristics and individual attributes and attitudes using multilevel logistic regression. Multilevel modeling is different than single-level regression in that it adjusts for biased standard errors in a hierarchical framework. In data used in this study, the residuals for individuals within a given congregation do not meet the assumption of independence in single-level regression. Calculating an approximate intra-class correlation for multilevel models with discrete dependent variables determines that the correlation in biblical literalism between two randomly selected congregants in the same, randomly chosen, congregation is $.403 .{ }^{9}$ In other words, $40 \%$ of the total variance in biblical literalism can be attributed to the congregation in which people worship. This is a sizeable ICC in comparison with values typical in other organizational research areas that frequently range from $5 \%$ to 20\% (Snijders and Roel, 1999, p. 46). Multilevel modeling takes the within-congregation covariance between individuals into consideration for modeling contextual effects. Multilevel modeling also allows the estimation of cross-level interactions between congregational factors and individual-level predictors. Put differently, this is akin to focusing on the slopes of persons' attributes (e.g., the effects of individual educational attainment on biblical literalism) and examining how the slopes vary across congregation characteristics (e.g., the proportion college graduate in the congregation) to conclude whether the latter conditions the former's effect on biblical literalism. Because literalism is a binary dependent variable, Bernoulli distribution with a logit link function for estimation is used.

The first model focuses on individual-level effects on biblical literalism, but also takes into account the clustering of persons within congregational units with a random coefficients regression model. ${ }^{10}$ Next, Model 2 examines congregation-level effects on biblical literalism, net of individual-level predictors. Model 3 adds cross-level interaction effects. This slopes-as-outcomes model considers whether congregational education moderates the effect of individual educational attainment on literalism.

\footnotetext{
${ }^{8}$ No evidence of multicollinearity was found upon examination of bivariate correlations of congregation- or person-level independent variables. All correlations are less than .5. All Variance Inflation Factors are below 2.0

${ }^{9}$ This one-way ANOVA with random effects model shows that there is statistically significant $(p<.001)$ congregation-level variance in the average log odds of biblical literalism (Raudenbush and Bryk, 2002). That is, biblical literalism varies across congregations.

${ }^{10}$ This modeling technique differs from previous single-level models of biblical literalism.
} 


\section{Results}

Table 2 presents coefficients and standard errors of three models of biblical literalism. Model 1 is consistent with the results of previous scholarship, but also adds new information by correcting for congregational nesting and also testing biblical literalism predictors in a sample of church attendees rather than a general sample of adults. Hypothesis 1 predicts that individual educational attainment will be associated with decreased likelihood of affirming biblical literalism. Consistent with Hypothesis 1, individuals with higher educational attainment are significantly less likely to affirm a literal view of the Bible, net of a range of religious and demographic attributes $(b=-.24, p<.001)$. To compare effect sizes (i.e., standardized effects), I report the change in the odds of literalism with a one-standard-deviation change (for continuous variables) in the explanatory variable. In terms of standardized effect, a one-standard-deviation increase in educational attainment is associated with a $34 \%$ drop in the odds of biblical literalism. The effect size of educational attainment is substantial; it is one of the strongest effects in the model. An alternate interpretation examines the change in the predicted probability of biblical literalism. Assuming average age, income, service attendance, etc., a white respondent with no child at home, no spouse in church, and a high school diploma as highest degree has a predicted probability of biblical literalism of .17. If the same respondent's highest degree is from a 4 year college or university, the predicted probability of biblical literalism would be .09 , a change in the predicted probability of .08-a considerable reduction. If the same individual has a graduate degree, the probability would be .07 , a reduction of .10 from the high school graduate probability. As will be discussed in the interpretation of Model 3, personal educational attainment's effect also significantly interacts with congregation-level education.

Other individual-level predictors are also worth noting in Model 1. A one-standard-deviation increase in age is associated with a $26 \%$ increase in the odds of biblical literalism. Having a child living at home is expected to increase the odds of affirming biblical literalism by $16 \%$. Compared to being non-Hispanic white, being Asian, black, or Hispanic is associated with a $46 \%, 52 \%$ and 33\% increase in the odds of biblical literalism respectively. The effect of income is also noteworthy; a one-standard-deviation increase in income is associated with a $15 \%$ reduction in the odds of having a literalist biblical view.

Table 2

Hierarchical bernoulli loeit models of biblical literalism.

\begin{tabular}{|c|c|c|c|c|c|c|}
\hline & \multicolumn{2}{|l|}{ Ml } & \multicolumn{2}{|l|}{ M2 } & \multicolumn{2}{|l|}{ M3 } \\
\hline & $b$ & SE & $b$ & SE & $b$ & SE \\
\hline Intercept & -0.60 & $0.08^{* * *}$ & 0.68 & $0.28^{* * *}$ & 0.17 & 0.27 \\
\hline \multicolumn{7}{|l|}{ Congregation level } \\
\hline \multicolumn{7}{|l|}{ Evangelical (ref) } \\
\hline Mainline protestant & & & -1.33 & $0.14^{* * *}$ & -1.33 & $0.16^{* * *}$ \\
\hline Catholic & & & -1.58 & $0.31^{* *}$ & -1.64 & $0.36^{* *}$ \\
\hline Other & & & -1.78 & $0.24^{* * *}$ & -1.71 & $0.24^{* * *}$ \\
\hline Size (LN) & & & 0.08 & 0.05 & 0.09 & 0.05 \\
\hline South & & & 0.20 & 0.11 & 0.22 & $0.10^{*}$ \\
\hline Proportion college graduate & & & -2.19 & $0.28^{* * *}$ & -0.73 & $0.31^{*}$ \\
\hline \multicolumn{7}{|l|}{ Individual level } \\
\hline Age & 0.01 & $0.00^{* * * *}$ & 0.01 & $0.00^{* * *}$ & 0.01 & $0.00^{* * *}$ \\
\hline Female & 0.01 & 0.02 & 0.00 & 0.02 & 0.00 & 0.02 \\
\hline Married & -0.03 & 0.03 & 0.00 & 0.02 & -0.01 & 0.02 \\
\hline Child at home & 0.15 & $0.02^{* * *}$ & 0.15 & $0.02^{* * * *}$ & 0.14 & $0.02^{* * *}$ \\
\hline Income & -0.11 & $0.01^{* * * *}$ & -0.11 & $0.01^{* * * *}$ & -0.11 & $0.01^{* * *}$ \\
\hline \multicolumn{7}{|l|}{ White (ref) } \\
\hline Asian & 0.38 & $0.06^{* * *}$ & 0.39 & $0.07^{* * * *}$ & 0.37 & $0.08^{* *}$ \\
\hline Black & 0.42 & $0.07^{* * *}$ & 0.35 & $0.08^{* * *}$ & 0.32 & $0.08^{* * *}$ \\
\hline Hispanic & 0.29 & $0.04^{* * *}$ & 0.23 & $0.04^{* * *}$ & 0.26 & $0.04^{* * *}$ \\
\hline Other & 0.06 & 0.05 & 0.06 & 0.05 & 0.07 & 0.05 \\
\hline Service attendance & 0.06 & $0.01^{* * * *}$ & 0.06 & $0.01^{* * * *}$ & 0.06 & $0.01^{* * *}$ \\
\hline Length of time at church & -0.01 & 0.01 & -0.01 & 0.01 & -0.01 & 0.01 \\
\hline Congregational spouse & 0.07 & $0.02^{* *}$ & 0.05 & $0.02^{*}$ & 0.06 & $0.02^{* *}$ \\
\hline Congregational friends & 0.06 & $0.01^{* * * *}$ & 0.05 & $0.01^{* * * *}$ & 0.05 & $0.01^{* * *}$ \\
\hline Educational attainment & -0.24 & $0.01^{* * *}$ & -0.23 & $0.01^{* * *}$ & -0.10 & $0.03^{* *}$ \\
\hline \multicolumn{7}{|c|}{ Cross-level interaction } \\
\hline \multicolumn{5}{|c|}{ Proportion college graduate $\times$ educational attainment } & -0.37 & $0.07^{* * *}$ \\
\hline-2 Log Likelihood & 92775.45 & & 92554.51 & & 92500.09 & \\
\hline AIC & 92819.45 & & 92610.51 & & 92558.09 & \\
\hline BIC & 92906.54 & & 92721.35 & & 92672.88 & \\
\hline
\end{tabular}

Note: Unstandardized coefficients and standard errors are reported. All coefficients are EM LaPlace estimates. Individual-level $N=100,009$; congregationlevel $N=387$.

${ }^{*} p<.05$.

** $p<.01$.

*** $p<.001$. 
Model 2 of Table 2 incorporates congregation-level variables. The smaller AIC score, compared with Model 1, indicates that this specification is a better fit to the data. Hypothesis 2 expected that individuals in congregations dominated by college graduates will be less likely to affirm a literal view of the Bible. The contextual effect of congregational education provides support for Hypothesis 2. As the proportion of college graduates in congregations rises, the likelihood of an individual affirming biblical literalism diminishes $(b=-2.19, p<.001)$. This contextual impact of congregation-level educational attainment remains in effect net of personal characteristics (e.g., individual education), congregational religious tradition, congregation size, and geography. In terms of magnitude of effect, a one-standard-deviation increase in congregation education is associated with a $28 \%$ drop in the odds of biblical literalism. Illustratively, a person in the least educated congregation is 7.4 times $\left(e^{0 \times-2.19} / e^{0.91 \times-2.19}\right)$ more likely to believe in literalism than the same person in the most educated congregation. Interestingly, another finding that can be pointed out here is the inverse; as the proportion non-college graduate in a congregation increases, worshippers are more likely to hold to a literal view of the Bible.

Model 3 incorporates a cross-level interaction term. The AIC statistics, which take into account sample size and degrees of freedom, indicate that this cross-level interaction model is the best fit to the data. This model tests Hypothesis 3: greater congregational dominance of college graduates will increase the effect of individual educational attainment on biblical literalism. In support of hypothesis 3, differences in the likelihood of members of different educational levels to affirm biblical literalism are conditioned by the educational composition of the congregation $(b=-.37, p<.001)$, such that high education individuals are even less likely to affirm biblical literalism in congregations where they predominate than in congregations where they are in the minority. This cross-level interaction effect holds net of various personal characteristics and important congregation variables such as religious tradition. Fig. 1 shows the predicted probability of affirming biblical literalism against the proportion of a congregation's membership that has a college degree for individuals of different levels of educational attainment. The influence of high education congregational context appears substantially greater for college graduates, but smaller for high school graduates or persons without a high school diploma. For example, compared to a church where $25 \%$ are college graduates, when in a church where half are college graduates, a person without a high school diploma is $10 \%$ less likely to affirm biblical literalism, a high school graduate is $13 \%$ less likely to affirm literalism, and a college graduate is $23 \%$ less likely to affirm literalism. The effects of the high education church context are clearly much larger for college graduates.

Fig. 1 also shows that the differences in literalist views of the Bible between college-educated worshippers and their non-college educated co-congregants are relatively small in congregations where the non-college educated predominate. However, the biblical literalism gap between high and low education individuals widens as those of high education come to dominate a congregation. Clearly, congregational higher education has a negative effect for everyone. The substantively important finding to note is the relative size of the difference in literalist belief across the college/non-college divide for churches with different educational make-ups. For example, Fig. 1 implies that in high-education churches, there should be less unity across educational groups than in low-education congregations (because differences in affirming a symbolically central belief are more pronounced).

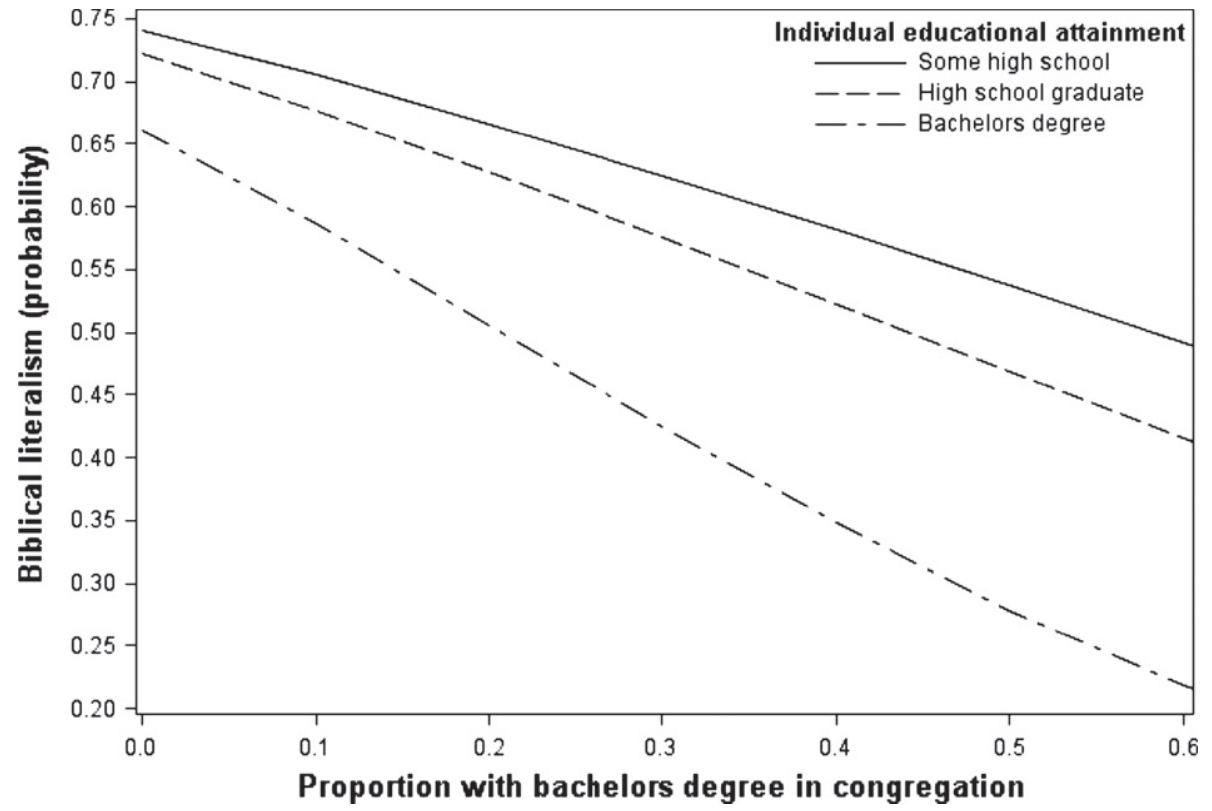

Fig. 1. Cross-level interaction between congregational education and individual education on biblical literalism. Note: Predictors not in figure are held constant at mean for continuous variables and zero for binary variables. 


\subsection{Supplementary analyses}

In addition to these models, I also examined the influence of social context on belief in biblical literalism (results shown in Appendix A). There are sound reasons to expect that the degree of immersion in the life of the a congregation may affect the cross-level interaction effect discussed above. Although it may matter for a college graduate how many of his or her co-congregants are also college educated, the extent of this effect may depend on how immersed the individual is in the congregation. In other words, the interactive relationship between congregational and individual education may be much more important for those whose social world is more strongly rooted in the congregation, and for those who spend time at church more frequently. I examined this idea by dividing the sample into low-medium-high groups in terms of their congregational friends, frequency of service attendance, and length of time at the congregation. ${ }^{11}$ The congregational education $\times$ individual education interaction effect remains statistically significant in all of these nine subsets of the data (see Table A1). Although the probability of biblical literalism tends to be slightly higher for the higher immersion subsets, the differences in the slope of congregational education for individuals of different educational attainment levels are not substantial (see Figs. A1-A3).

Finally, I investigated the possibility that selectivity may be an influence on results. I estimated models in a sample restricted to age groups likely to have completed formal education (over 30 or 35 years of age). In both the persons over 30 model and the persons over 35 model the focal interaction effect (congregational education $\times$ individual education) does not change in any meaningful way. I also restricted the data to individuals who have attended the congregation for 6 or more year and only retain persons over 30 or 35 . Again, the interaction effect is not substantially different. The results appear to be robust in these older, somewhat smaller samples, and in the samples restricted to persons who have attended their congregations longer.

\section{Discussion}

Based on a schema-resource model, prior work argues that education is a resource that shapes religious schemas, particularly a biblical literalist schema (Sherkat, 1998). Additionally, theory suggests that social contexts directly affect and interact with individual traits to influence religious beliefs (Sherkat, 2010). The present study contributes to this prior literature and advances our understanding of educational influences on the biblical literalist schema by considering the educational attainment of church-goers and the educational composition of their congregations using multilevel modeling. I argue that the interplay between social contexts and educational experiences tap both resources and schemas that shape individuals' view of the Bible. I also incorporate the idea of knowledge transfer from organizational science as a mechanism for understanding this interplay.

Consistent with the hypotheses, I document three main findings. First, analysis of this study's nested sample of church attendees confirms results from national samples of Americans. For church goers, individual educational attainment has a strong negative effect on the likelihood of a literal view of the Bible. ${ }^{12}$ Second, the present study systematically examines how the educational make-up of churches is linked to biblical literalism. I find that in churches dominated by those with college degrees, a given individual is less likely to espouse literalist views of the Bible. The importance of the educational composition of congregations remains substantial in these data (one of the largest effects) even after taking into account key individual characteristics such as gender, children, income, race, age, and religious participation as well as congregational factors including religious tradition, congregation size, and geographic location.

Finally, I test a cross-level interaction effect between congregational and individual educational attainment. I find that the contextual effect of congregational education is stronger for the more educated church member. This contextual effect complicates the story of how personal educational attainment impacts view of the Bible. For example, when in a congregation with few college degree holders, the probability of a college graduate adhering to biblical literalism is greater than the probability of a high school graduate affirming literalism in a congregation dominated by college graduates. Put differently, congregational context moderates personal educational characteristics to such an extent that literalism is less likely for low education persons than high education persons when high education persons are in low education churches and low education persons are in high education churches. Though there is a negative influence of high education congregational context on espousal of biblical literalism for persons of any educational attainment level, the contextual effect appears strongest for college graduates, weaker for persons with a high school diploma, and weakest for persons with less than a high school diploma. This suggests that anti-literalist orientations in high education churches are more fully absorbed by those with greater educational attainment - especially those who have graduated from college. Additionally, the gap in literalist belief

\footnotetext{
11 In a test of more complex interactions in the full sample, I found no significant three-way interaction effects for congregational friends (friends $\times$ congregational education $\times$ individual education), church attendance (attendance $\times$ congregational education $\times$ individual education), or length of time in congregation (length of time $\times$ congregational education $\times$ individual education).

12 To be sure, prior research has demonstrated the liberalizing impact of educational attainment on a range of beliefs, but recent work on educational influences on religious belief and practice has shown mixed results (Mayrl and Oeur, 2009), and few studies have compared college attendees with nonattendees. This gap prompts further examination of person-level education's influence on particular religious outcomes such as biblical literalism, comparing persons with differing exposure to college. The present study's individual-level education finding confirms prior research, and also adds new information by correcting for congregational nesting and also testing predictors of biblical literalism in a large sample of church attendees rather than a general sample of adults.
} 
widens between low and high education persons in high education churches. But it should be kept in mind that a low education person is still less likely to be literalist in a high education church than in a low education church.

These findings have implications for understanding educational attainment, congregational contexts, and view of the Bible. In these data, congregational education has a direct negative impact on individual biblical literalism, regardless of personal characteristics. Such contextual effects extend the prior work of scholars who emphasized the power of immediate congregational social contexts in shaping religious beliefs (Wuthnow, 1996; Stark and Bainbridge, 1980). The contextual effects modeled here may also help us better understand how religious subcultures maintain belief through plausibility structures in society (Berger, 1967; Smith et al., 1998). When congregations are composed of more people who have experienced higher education, the plausibility structure is different than a social context where few members have been shaped by higher education. More than simply imparting information and cognitive skills, educational experiences come to shape lasting cultural distinctions between people of differing educational backgrounds and statuses (Bourdieu, 1984; Lizardo, 2006). These cultural boundaries promote homogeneity in cultural tastes and attitudes through group sanctioning within educational status groups (Kalmijn and Kraaykamp, 2007). As a result, biblical literalism becomes a form of cognitive deviance (or at least significantly less palatable) in groups dominated by those who have experienced higher education institutions and associated cultural tastes and moral orientations. Furthermore, the data analyzed in this study indicate that even those who have not shared the experience of higher education are less likely to hold to a literal view of the Bible when in congregations dominated by those who have.

Not only do individual educational attainment and congregation educational make-up have independent negative effects on biblical literalism, but their interaction shows that high education individuals are even less likely to hold literalist views in congregations where they make up the majority than in congregations where they are the minority. In keeping with the organizational science idea of "absorptive capacity" (Tsai, 2001), the enlarged literalism gap likely exists because persons with more education are better able to soak up and assimilate the anti-literalist orientation surrounding them, allowing it more sway over their own view of biblical scripture. Alternatively, skeptical attitudes toward the literal validity of some biblical texts may lie dormant in a person's mind unless activated by the skepticism others. For instance, fellow Sunday school members may mention how they stopped understanding Genesis 1-3 as referring to literal days after taking biology classes in college and how this prompted them to explore other hermeneutical approaches to Genesis such as understanding the creation story as referring to an ancient Near Eastern temple construction narrative, not 6 24-hour days. Such a congregational situation would likely call to mind similar biblicism-eroding experiences from an individual's own college days.

I also found there to be an enlarged literalism gap between college and non-college educated persons when in high education congregations. Speculatively, the widened gap in belief between the college/non-college groups in more educated churches may represent the unraveling of within-congregation solidarity. Such an erosion of solidarity would be consequential considering the fact that previous research shows biblical literalism to be a salient symbolic belief linked to variety of religious and non-religious attitudes and behaviors. It follows that high education church contexts may set the stage for the eruption of church conflict or a least diminished collective sense of community due to the lack of cultural unanimity (see Vaisey, 2007). Recent research shows that homogeneity of biblical belief in churches bolsters congregants' sense of belonging (Stroope, 2010). If liberal churches are comprised of more highly educated people, the biblical belief gap (i.e., heterogeneity of biblical belief) between more and less educated people within these churches likely reduces congregants' belonging feelings and may help explain declines in overall levels of membership in liberal churches. Likewise, if the positive effects of belief homogeny strengthens belonging and associated positive effects on membership and participation. More research should be conducted along these lines. Diminished solidarity may also influence more than congregational community feeling because conflict and negative interaction at church is inversely related to physical health (Krause and Wulff, 2005). Future work should explore the link between educational make-up of congregations, conflict, and health.

This study has documented new findings, but there remain ways that future research could improve upon limitations in the data. Although the present study took steps to account for selection effects, multilevel longitudinal data on congregations and members could help further assess the extent of selection that may exist. For instance, such data would facilitate more precise estimation of status group effects and how status groups differentially activate people of differing educational attainment, holding constant earlier adherence to biblical literalism. Also, prior research indicates that literalists enroll in fewer years of formal education (Darnell and Sherkat, 1997) and have less elaborate vocabularies (Sherkat, 2010). It is possible that because of biblical literalists' lower educational credentials and smaller verbal repertoires, they then homophilously seek out congregations where plain speech is more prevalent and references to college experiences less common. Multilevel panel data would help isolate the trajectory of literalist schema maintenance for literalists who do go to college and then congregate with similarly educated others.

Other limitations of the study should be noted. It is important to interpret the findings of this study in light of the fact that its sample is from persons who attended weekend worship services. It is likely that the sample consists of a portion of the American public that attends church at least somewhat regularly. Due to the likelihood that the sample is relatively religious in this regard, caution should be used in generalizing. Finally, although this study has presented a set of likely mechanisms for the amplifying effect of congregational context, the available measures in the data do not permit me to identify which mechanisms are the most important in this context. Future work could employ data that makes adjudication between these mechanisms possible.

The arguments of this article present a picture of personal and contextual educational attainment eroding literalist schemas. However, education does not necessarily diminish all religious beliefs or religious commitment in general. On the 
contrary, it is possible that education may bolster some religious schemas by furnishing adherents with cognitive tools to help innovatively rejuvenate traditional beliefs (Finke, 2004; Smith et al., 1998), or further systematize and elaborate especially complex conservative beliefs such as dispensational theology. In this article, I have focused on biblical literalism because of its importance for a wide range of outcomes. But this study's findings have implications for other religious beliefs, moral schemas, religious practices, and resources. Recent work has complicated our understanding of individual educational attainments' effects on religious outcomes (Uecker et al., 2007) as well as the effects of secular and religious educational contexts (Barrett et al., 2007; Hill, 2009). Congregational educational attainment and its interplay with personal education should also be explored in connection with various other religious forms, expressions, and consequences.

If "faith communities in which people worship together are arguably the single most important repository of social capital in America" (Putnam, 2000, p. 66), congregational characteristics may be important not only for various religious outcome, but also for a variety of non-religious aspects of social life. In addition to diminishing or bolstering religious beliefs through the concentration of educational experience, a variety of the attributes of individuals who compose congregations likely provide strong plausibility structures for other social attitudes or behaviors such as bridging civic engagement (Tolbert et al., 1998). Another promising avenue of research revolves around congregations' influence on health behaviors (Blanchard et al., 2008; Ellison et al., 2008). Congregants may strongly influence each other's health-related behavior because congregants can collectively exert social control and apply moral pressure on fellow worshippers' behaviors (Gillum, 2005). The composition of religious congregations along various lines of human capital, and the associated contextual effects, remain an underexplored but potentially fruitful area for multilevel study.

The relationship between individuals and the social context that surrounds them is a fundamental issue in social theory and research. One of the most important social contexts for religion is the congregation, especially in the United States (Warner, 1994). Sociologists of religious organizations argue that the context of the congregation can align participants with other congregation members, and certain individual attributes may amplify the impact of characteristics of the congregational context (Scheitle and Finke, 2008). Building on individual-level research on education and biblical literalism, the findings of this paper further support theories of congregational contextual effects by showing that individuals in highly educated congregations are significantly less likely to be biblical literalists. This remains so over and above the individual's own characteristics, but the contextual effect is strongest for more highly educated worshippers. When congregations have many people who have experienced higher education, a member is less likely to maintain a literal view of the Bible. In other words, biblicism is less plausible when fellow worshippers are highly educated, regardless of an individual's own education.

Table A1

Hierarchical bernoulli logit models of biblical literalism by subset.

\begin{tabular}{|c|c|c|c|c|c|c|}
\hline & \multicolumn{2}{|c|}{$\begin{array}{l}\text { Ml } \\
\text { Low congregational friends }\end{array}$} & \multicolumn{2}{|c|}{$\begin{array}{l}\text { M2 } \\
\text { Medium congregational } \\
\text { friends }\end{array}$} & \multicolumn{2}{|c|}{$\begin{array}{l}\text { M3 } \\
\text { High congregational friends }\end{array}$} \\
\hline & $b$ & SE & $b$ & SE & $b$ & SE \\
\hline Proportion college graduate & -0.30 & 0.36 & -1.08 & $0.33^{* *}$ & -0.62 & 0.49 \\
\hline Educational attainment & -0.09 & $0.03^{* *}$ & -0.13 & $0.02^{* * *}$ & -0.05 & 0.04 \\
\hline Proportion college graduate $\times$ educational attainment & -0.35 & $0.06^{* * *}$ & -0.31 & $0.04^{* * *}$ & -0.42 & $0.09^{* * *}$ \\
\hline$N$ & 34,160 & & 52,333 & & 13,546 & \\
\hline \multirow[t]{4}{*}{-2 Log Likelihood } & 31023.85 & & 48058.13 & & 14194.76 & \\
\hline & \multirow{2}{*}{\multicolumn{2}{|c|}{$\begin{array}{l}\text { M4 } \\
\text { Low service attendance }\end{array}$}} & \multirow{2}{*}{\multicolumn{2}{|c|}{$\begin{array}{l}\text { M5 } \\
\text { Medium service attendance }\end{array}$}} & \multirow{2}{*}{\multicolumn{2}{|c|}{$\begin{array}{l}\text { M6 } \\
\text { High service attendance }\end{array}$}} \\
\hline & & & & & & \\
\hline & $b$ & $\mathrm{SE}$ & $b$ & SE & $b$ & SE \\
\hline Proportion college graduate & -0.06 & 0.40 & -0.78 & $0.30^{* *}$ & -0.54 & 0.54 \\
\hline Educational attainment & -0.09 & $0.03^{* *}$ & -0.09 & $0.02^{* * *}$ & -0.10 & $0.04^{* *}$ \\
\hline Proportion college graduate $\times$ educational attainment & -0.41 & $0.07^{* * *}$ & -0.37 & $0.06^{* * *}$ & -0.41 & $0.10^{* * *}$ \\
\hline$N$ & 22,399 & & 63,161 & & 14,480 & \\
\hline \multirow[t]{4}{*}{-2 Log Likelihood } & 20003.92 & & 58632.08 & & 14212.1 & \\
\hline & M7 & & \multirow{2}{*}{\multicolumn{2}{|c|}{$\begin{array}{l}\text { M8 } \\
\text { Medium length of time at } \\
\text { church }\end{array}$}} & \multirow{2}{*}{\multicolumn{2}{|c|}{$\begin{array}{l}\text { M9 } \\
\text { High length of time at } \\
\text { church }\end{array}$}} \\
\hline & \multicolumn{2}{|c|}{$\begin{array}{l}\text { Low length of time at } \\
\text { church }\end{array}$} & & & & \\
\hline & $b$ & SE & $b$ & SE & $b$ & SE \\
\hline Proportion college graduate & 0.16 & 0.57 & -1.08 & $0.35^{* *}$ & -0.48 & 0.40 \\
\hline Educational attainment & -0.09 & $0.04^{*}$ & -0.08 & $0.03^{* *}$ & -0.10 & $0.03^{* *}$ \\
\hline Proportion college graduate $\times$ educational attainment & -0.43 & $0.10^{* * *}$ & -0.38 & $0.06^{* * *}$ & -0.42 & $0.08^{* * *}$ \\
\hline & 10,129 & & 45,744 & & 28,931 & \\
\hline-2 Log Likelihood & 9517.82 & & 40972.29 & & 27989.26 & \\
\hline
\end{tabular}

Note: Controls shown in model 3 of Table 2 are included in models; results suppressed for brevity. Unstandardized coefficients and standard errors are reported. All coefficients are EM LaPlace estimates. 
Additionally, individual education and congregational education taken in concert have amplifying effects for reducing affirmations of a literal Bible.

\section{Appendix A}

See Table A1 and Figs. A1-A3.

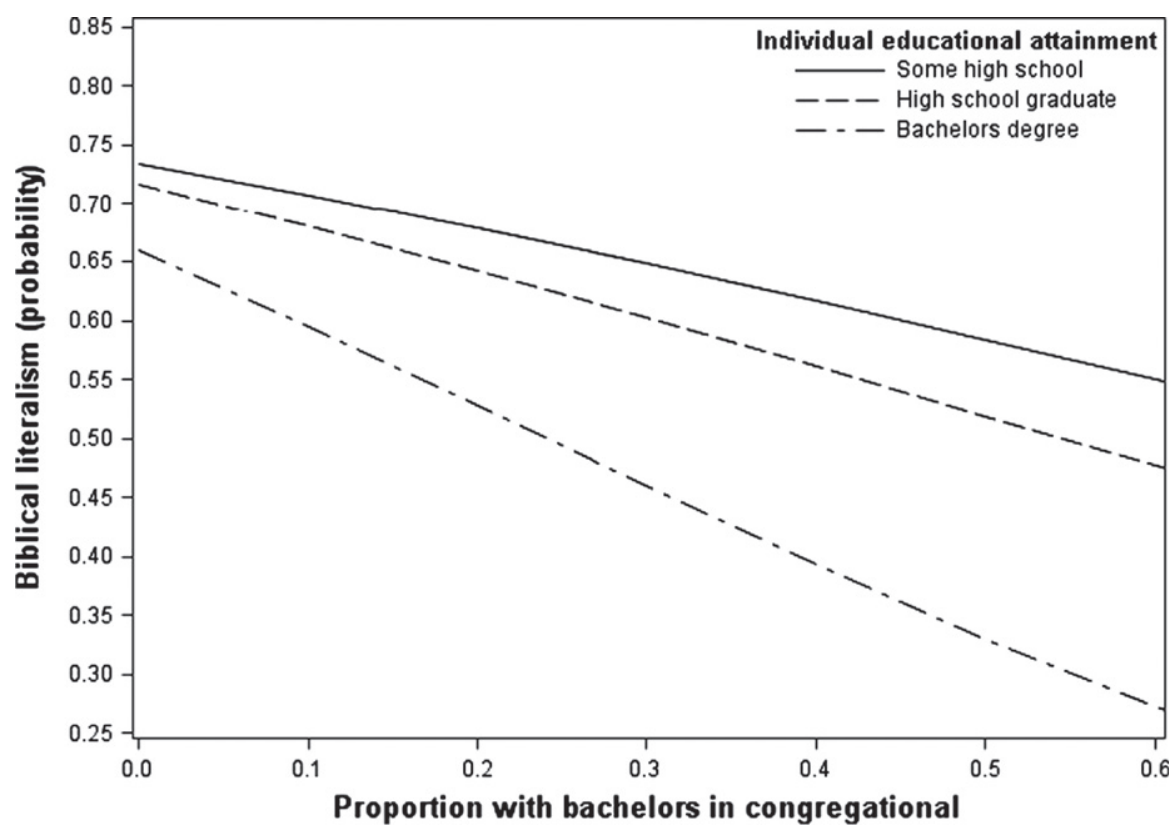

Fig. A1. Cross-level interaction by low congregational friends. Note: Predictors not in figure are held constant at mean for continuous variables and zero for binary variables.

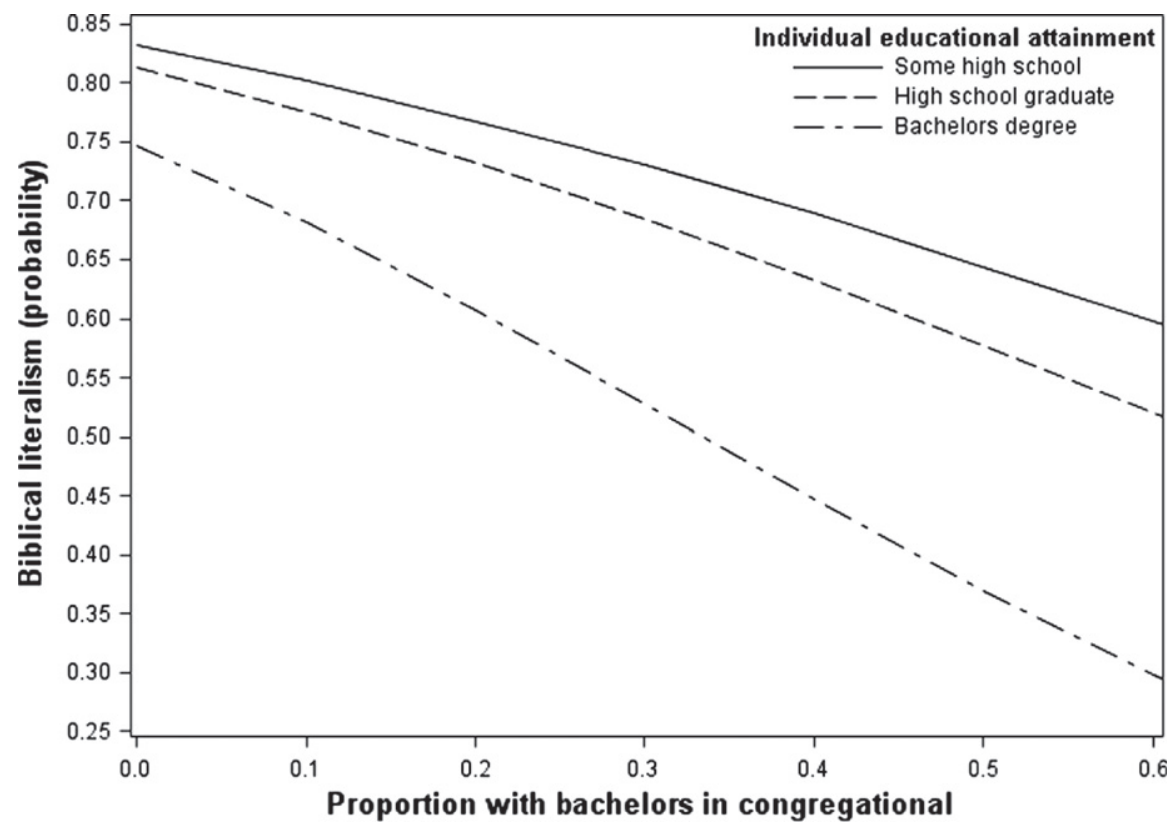

Fig. A2. Cross-level interaction by medium congregational friends. Note: Predictors not in figure are held constant at mean for continuous variables and zero for binary variables. 


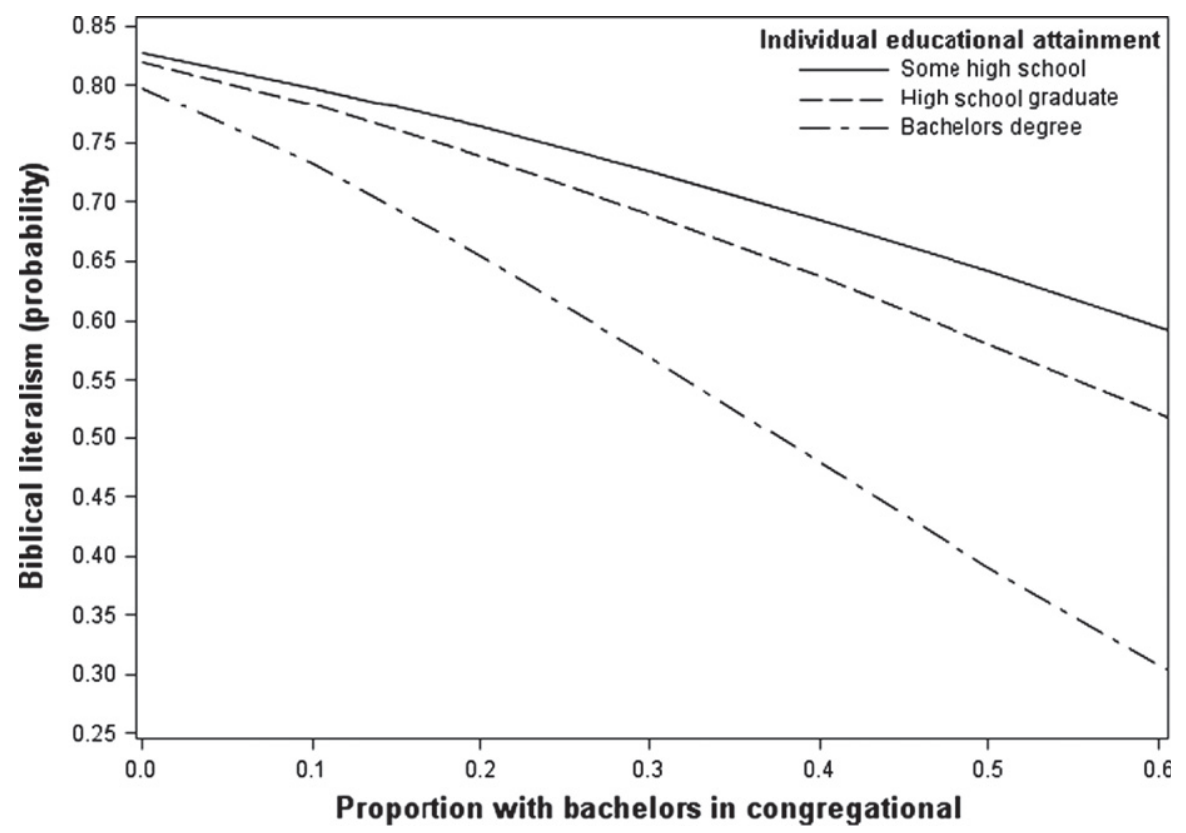

Fig. A3. Cross-level interaction by high congregational friends. Note: Predictors not in figure are held constant at mean for continuous variables and zero for binary variables.

\section{References}

Allison, Paul D., 2001. Missing Data. Sage Publications, Thousand Oaks, CA.

Almond, Gabriel A., Emmanuel Sivan, R., Appleby, Scott, 1995. Fundamentalism: genus and species. In: Fundamentalisms Comprehended. University of Chicago Press, Chicago, pp. 399-424.

American Association for Public Opinion Research, 2008. Do Response Rates Matter? <http://www.aapor.org> (accessed 23.11.10).

Ammerman, Nancy Tatom, 1987. Bible Believers: Fundamentalists in the Modern World. Rutgers University Press, New Brunswick.

Arnett, Jeffrey Jensen, Jensen, Lene Arnett, 2002. A congregation of one. Journal of Adolescent Research 17, 451-467 (accessed 25.12.10).

Bader, Christopher D., Desmond, Scott A., Carson Mencken, F., Johnson, Byron R., 2010. Divine justice: the relationship between images of god and attitudes toward criminal punishment. Criminal Justice Review 35, 90-106.

Bader, Christopher D., Froese, Paul, 2005. Images of God: the effect of personal theologies on moral attitudes, political affiliation, and religious behavior. Interdisciplinary Journal of Research on Religion $1,11$.

Barrett, Jennifer B., Pearson, Jennifer, Muller, Chandra, Frank, Kenneth A., 2007. Adolescent religiosity and school contexts. Social Science Quarterly 88, $1024-1037$.

Bartkowski, John, 1996. Beyond biblical literalism and inerrancy: conservative Protestants and the hermeneutic interpretation of scripture. Sociology of Religion 57, 259-272.

Bartkowski, John P., Wilcox, W. Bradford, 2000. The conservative protestant child discipline: the case of parental yelling. Social Forces 79, $265-296$.

Bell, Daniel, 1973. The Coming of Post-industrial Society; a Venture in Social Forecasting. Basic Books, New York.

Berger, Peter L., 1967. The Sacred Canopy: Elements of a Sociological Theory of Religion. Doubleday, Garden City, NY.

Blanchard, Troy C., Bartkowski, John P., Matthews, Todd L., Kerley, Kent R., 2008. Faith, morality and mortality: the ecological impact of religion on population health. Social Forces 86, 1591-1620.

Bourdieu, Pierre, 1984. Distinction: A Social Critique of the Judgment of Taste. Harvard University Press, Cambridge, MA.

Bruce-Briggs, B., 1979. The New Class? New Brunswick. Transaction Books, NJ.

Burdette, Amy M., Ellison, Christopher G., Sherkat, Darren E., Gore, Kurt A., 2007. Are there religious variations in marital infidelity? Journal of Family Issues 28, 1553-1581.

Cherry, Conrad, DeBerg, Betty A., Porterfield, Amanda, 2001. Religion on Campus. University of North Carolina Press, Chapel Hill.

Connor, Phillip, 2009. International migration and religious participation: the mediating impact of individual and contextual effects. Sociological Forum 24 , 779-803.

Cornwall, Marie, 1989. The determinants of religious behavior: a theoretical model and empirical test. Social Forces 68, $572-592$.

Cornwall, Marie, 1987. The social bases of religion: a study of factors influencing religious belief and commitment. Review of Religious Research 29, 44-56.

Darnell, Alfred, Sherkat, Darren E., 1997. The impact of protestant fundamentalism on educational attainment. American Sociological Review 62, 306-315.

Dillon, Michele, 1996. The persistence of religious identity among college Catholics. Journal for the Scientific Study of Religion 35, 165-170 (accessed 25.11.10).

Dougherty, Kevin D., Andrew, L. Whitehead, 2011. A place to belong: small group involvement in religious congregations. Sociology of Religion 72, 91-111.

Ecklund, Elaine Howard, Park, Jerry Z., 2009. Conflict between religion and science among academic scientists? Journal for the Scientific Study of Religion 48, 276-292.

Ecklund, Elaine Howard, Scheitle, Christopher P., 2007. Religion among academic scientists: distinctions, disciplines, and demographics. Social Problems 54, 289-307.

Ellison, Christopher G., Bartkowski, John P., 1997. Religion and the legitimation of violence: the case of conservative Protestantism and corporal punishment. In: The Web of Violence: From Interpersonal to Global. University of Illinois Press, Urbana, IL, pp. 45-67.

Ellison, Christopher G. et al, 2008. Congregational support networks, health beliefs, and annual medical exams: findings from a nationwide sample of presbyterians. Review of Religious Research 50, 176-193.

Ellison, Christopher G., Sherkat, Darren E., 1993. Conservative Protestantism and support for corporal punishment. American Sociological Review 58, 131144. 
Evans, John H., Evans, Michael S., 2010. Arguing against Darwinism: religion, science, and public morality. In: The New Blackwell Companion to the Sociology of Religion. Blackwell, New York, pp. 286-308.

Finke, Roger, 2004. Innovative returns to tradition: using core teachings as the foundation for innovative accommodation. Journal for the Scientific Study of Religion 43, 19-34.

Froese, Paul, Bader, Christopher D., 2010. America's Four Gods: What We Say About God and What That Says About Us. Oxford University Press, New York.

Froese, Paul, Bader, Christopher D., 2007. God in America: why theology is not simply the concern of philosophers. Journal for the Scientific Study of Religion 46, 465-481.

Froese, Paul, Bader, Christopher, Smith, Buster, 2008. Political tolerance and God's wrath in the United States. Sociology of Religion 69, 29-44.

Funk, Richard B., Willits, Fern K., 1987. College attendance and attitude change: a panel study, 1970-81. Sociology of Education 60, $224-231$.

Gillum, R.F., 2005. Frequency of attendance at religious services and cigarette smoking in American women and men: the third national health and nutrition examination survey. Preventive Medicine 41, 607-613.

Gould, Roger.V., 2003. Why do networks matter? Rationalist and structuralist interpretations. In: Social Movements and Networks; Social Movements and Networks. Oxford U Press, Oxford, United Kingdom, pp. 233-257.

Gross, Neil, Simmons, Solon, 2009. The religiosity of American college and university professors. Sociology of Religion 70, $101-129$.

Hill, Jonathan P., 2009. Higher education as moral community: institutional influences on religious participation during college. Journal for the Scientific Study of Religion 48, 515-534.

Hill, Jonathan P., Olson, Daniel V.A., 2009. Market share and religious competition: do small market share congregations and their leaders try harder? Journal for the Scientific Study of Religion 48, 629-649.

Himmelfarb, Harold S., 1979. Agents of religious socialization among American Jews. Sociological Quarterly 20, 477-494.

Hoffmann, John E., Bartkowski, John E., 2008. Gender, religious tradition and biblical literalism. Social Forces 86, $1245-1272$.

Hood, Ralph W., Hill, Peter C., Williamson, Paul W., 2005. The Psychology of Religious Fundamentalism. Guildford Press, New York.

Hout, Michael, Greeley, Andrew, Wilde, Melissa J., 2001. The demographic imperative in religious change in the United States. American Journal of Sociology 107, 468-500.

Hunter, James Davison, 1987. Evangelicalism: The Coming Generation. University of Chicago Press, Chicago.

Hyman, Herbert Hiram, Wright, Charles Robert, 1979. Education's Lasting Influence on Values. University of Chicago Press, Chicago.

Iannaccone, Lawrence R., 1994. Why strict churches are strong. American Journal of Sociology 99, 1180-1211.

Ingersoll-Dayton, Berit, Krause, Neal, Morgan, David, 2002. Religious trajectories and transitions over the life course. International Journal of Aging and Human Development 55, 51-70 (accessed 16.02.11).

Jelen, Ted G., Wilcox, Clyde, Smidt, Corwin E., 1990. Biblical literalism and inerrancy: a methodological investigation. Sociological Analysis 51, 307-313.

Kalmijn, Matthijs, Kraaykamp, Gerbert, 2007. Social stratification and attitudes: a comparative analysis of the effects of class and education in Europe. British Journal of Sociology 58, 547-576.

Krause, Neal, Wulff, Keith M., 2005. Church-based social ties, a sense of belonging in a congregation, and physical health status. International Journal for the Psychology of Religion 15, 73-93.

Lee, Jenny J., 2002. Religion and college attendance: change among students. The Review of Higher Education 25, 369-384.

Lindsay, D. Michael, 2007. Faith in the Halls of Power: How Evangelicals Joined the American Elite. Oxford University Press, New York.

Lizardo, Omar, 2006. How cultural tastes shape personal networks. American Sociological Review 71, 778-807.

Lofland, John, Stark, Rodney, 1965. Becoming a world-saver: a theory of conversion to a deviant perspective. American Sociological Review 30, 862-875 (accessed 13.02.11).

Marsden, George M., 1980. Fundamentalism and American Culture: The Shaping of Twentieth Century Evangelicalism, 1870-1925. Oxford University Press, New York.

Marsden, George M., 1994. The soul of the American University: From Protestant Establishment to Established Nonbelief. Oxford University Press, New York.

Mayrl, Damon, Oeur, Freeden, 2009. Religion and higher education: current knowledge and directions for future research. Journal for the Scientific Study of Religion 48, 260-275.

Norris, Pippa, Inglehart, Ronald, 2004. Sacred and Secular: Religion and Politics Worldwide. Cambridge University Press, New York.

Ohlander, Julianne, Batalova, Jeanne, Treas, Judith, 2005. Explaining educational influences on attitudes toward homosexual relations. Social Science Research 34, 781-799.

Pallas, Aaron M., 2000. The effects of schooling on individual lives. In: Maureen, T. (Ed.), Handbook of the Sociology of Education. Kluwer Academic/Plenum, New York, pp. 499-525.

Pascarella, Ernest T., Terenzini, Patrick T., 2005. How College Affects Students: A Third Decade of Research, vol. 2. Jossey-Bass Publishers, San Francisco.

Putnam, Robert D., 2000. Bowling Alone: The Collapse and Revival of American Community. Simon \& Schuster, New York.

Raudenbush, Stephen W., Bryk, Anthony S., 2002. Hierarchical Linear Models: Applications and Data Analysis Methods. Sage, Newbury Park, CA.

Regnerus, Mark D., Smith, Christian, Smith, Brad, 2004. Social context in the development of adolescent religiosity. Applied Developmental Science 8, 27-38.

Reimer, Sam, 2010. Higher education and theological liberalism: revisiting the old issue. Sociology of Religion. <http://socrel.oxfordjournals.org/cgi/doi/ $10.1093 /$ socrel/srq049>.

Roof, Wade Clark, McKinney, William, 1987. American Mainline Religion: Its Changing Shape and Future. Rutgers University Press, New Brunswick, NJ.

Rubin, Donald B., 1987. Multiple Imputation for Nonresponse in Surveys. John Wiley and Sons, Inc.

Scheitle, Christopher P., Adamczyk, Amy., 2009. It takes two: the interplay of individual and group theology on social embeddedness. Journal for the Scientific Study of Religion 48, 16-29.

Scheitle, Christopher P., Finke, Roger, 2008. Maximizing congregational resources: selection versus production. Social Science Research $37,815-827$.

Schwadel, Philip, 2011. Age, period, and cohort effects on religious activities and beliefs. Social Science Research 40, 181-192 (accessed 16.02.11).

Sewell, William H., 1992. A theory of structure: duality, agency, and transformation. American Journal of Sociology 98, 1-29.

Sewell, William Hamilton, 2005. Logics of History: Social Theory and Social Transformation. University of Chicago Press, Chicago.

Sherkat, Darren E., 1998. Counterculture or continuity? Competing influences on baby boomers' religious orientations and participation. Social Forces 76, $1087-1114$

Sherkat, Darren E., 2007. Religion and Higher Education: The Good, the Bad, and the Ugly. SSRC Web Forum. <http://religion.ssrc.org/reforum/Sherkat.pdf>.

Sherkat, Darren E., 2010. Religion and verbal ability. Social Science Research 39, 2-13.

Sherkat, Darren E., Cunningham, Shannon A., 1998. Extending the semi-involuntary institution: regional differences and social constraints on private religious consumption among African Americans. Journal for the Scientific Study of Religion 37, 383-396.

Sherkat, Darren E., Darnell, Alfred, 1999. The effect of parents' fundamentalism on children's educational attainment: examining differences by gender and children's fundamentalism. Journal for the Scientific Study of Religion 38, 23-35.

Sherkat, Darren E., Ellison, Christopher G., 2007. Structuring the religion-environment connection: identifying religious influences on environmental concern and activism. Journal for the Scientific Study of Religion 46, 71-85.

Sherkat, Darren E., Ellison, Christopher G., 1997. The cognitive structure of a moral crusade: conservative Protestantism and opposition to pornography. Social Forces 75, 957-980 (accessed 25.11.10).

Sikkink, David, 1999. The social sources of alienation from public schools. Social Forces 78, 51-87.

Simmel, Georg, 1898. A contribution to the sociology of religion. In: Simmel, Georg (Ed.), Essays on Religion. Yale University Press, New Haven, CT, pp. 101120.

Singer, Eleanor, 2006. Special issue on nonresponse bias in household surveys. Public Opinion Quarterly 70, 639-810. 
Smith, Christian, 2003a. The Secular Revolution: Power, Interests, and Conflict in the Secularization of American Public Life. University of California Press, Berkeley.

Smith, Christian, 2003b. Theorizing religious effects among American adolescents. Journal for the Scientific Study of Religion 42, 17-30.

Smith, Christian, Emerson, Michael, Gallagher, Sally, Kennedy, Paul, Sikkink, David, 1998. American Evangelicalism: Embattled and Thriving. University of Chicago Press, Chicago.

Smith, Christian, Snell, Patricia, 2009. Souls in Transition: The Religious and Spiritual Lives of Emerging Adults. Oxford University Press, New York.

Snijders, Tom A.B., Roel, J. Bosker, 1999. Multilevel Analysis: An Introduction to Basic and Advanced Multilevel Modeling. Sage Publications, Thousand Oaks.

Stark, Rodney, Bainbridge, William Sims, 1980. Networks of faith: interpersonal bonds and recruitment to cults and sects. American Journal of Sociology 85, $1376-1395$.

Stroope, Samuel, 2011. Caste, class, and urbanization: the shaping of religious community in contemporary India. Social Indicators Research. doi:10.1007/ s11205-011-9784-y.

Stroope, Samuel, 2010. Cultivating Gemeinschaft: Organizational Factors and a Sense of Belonging in Religious Congregations. Paper Presented at the Annual Meeting of the Society for the Scientific Study of Religion, Baltimore.

Stump, Roger W., 1984. Regional migration and religious commitment in the United States. Journal for the Scientific Study of Religion 23, $292-303$.

Thornton, Arland, Axinn, William G., Hill, Daniel H., 1992. Reciprocal effects of religiosity, cohabitation, and marriage. The American Journal of Sociology 98 , 628-651 (accessed 16.02.11)

Tolbert, Charles M., Lyson, Thomas A., Irwin, Michael D., 1998. Local capitalism, civic engagement, and socioeconomic well-being. Social Forces 77, 401-427.

Tsai, Wenpin, 2001. Knowledge transfer in intraorganizational networks: effects of network position and absorptive capacity on business unit innovation and performance. The Academy of Management Journal 44, 996-1004.

Uecker, Jeremy E., Regnerus, Mark D., Vaaler, Margaret L., 2007. Losing my religion: the social sources of religious decline in early adulthood. Social Forces $85,1667-1692$.

Vaisey, Stephen, 2007. Structure, culture, and community: the search for belonging in 50 urban communes. American Sociological Review 72, 851-873.

Village, Andrew, 2005. Assessing belief about the Bible: a study among anglican laity. Review of Religious Research 46, 243-254

Village, Andrew, 2007. The Bible and Lay People: An Empirical Approach to Ordinary Hermeneutics. Ashgate, Aldershot, England, Burlington, VT.

Von Hippel, Paul T., 2007. Regression with missing Ys: an improved strategy for analyzing multiply imputed data. Sociological Methodology 37, 83-117.

Walzer, Susan, 1994. The role of gender in determining abortion attitudes. Social Science Quarterly 75, 687-693.

Warner, R. Stephen, 1994. The place of congregation in the contemporary American religious configuration. In: American Congregations: New Perspectives in the Study of Congregations. University of Chicago Press, Chicago, pp. 54-100.

Whitehead, Andrew L., 2010. Financial commitment within federations of small groups: the effect of cell-based congregational structure on individual giving. Journal for the Scientific Study of Religion 49, 640-656.

Wilcox, Clyde, 1992. Race, religion, region and abortion attitudes. Sociological Analysis 53, 97-105.

Wolkomir, M., Futreal, M., Woodrum, E., Hoban, T., 1997. Substantive religious belief and environmentalism. Social Science Quarterly 78, 96-108.

Woodberry, Robert D., Christian, Smith, 1998. Fundamentalism et al.: Conservative Protestants in America. Annual Review of Sociology 24.

Woolever, Cynthia, Bruce, Deborah, 2002. A Field Guide to US Congregations: Who's Going Where and Why. Westminster John Knox Press, Louisville, KY.

Wuthnow, Robert, 1996. Restructuring of American religion: further evidence. Sociological Inquiry 66, 303-329.

Wuthnow, Robert, 1988. The Restructuring of American Religion: Society and Faith since World War II. Princeton University Press, Princeton, NJ.

Wuthnow, Robert, Christiano, Kevin, 1979. The effects of residential migration on church attendance in the United States. In: The Religious Dimension: New Directions in Quantitative Research. Academic Press, New York, pp. 257-274. 